\title{
Planning for an eco-city to sustainable urban environments International case studies
}

\author{
Dr. Reeman Mohammed Rehan \\ Associate professor \\ Department of architecture \\ Faculty of engineering - Helwan University
}

\begin{abstract}
An eco-city is a city designed and built with a thorough consideration of environmental impacts. In ecocities, inhabitants are dedicated to minimizing required inputs of energy, water, and food and to reducing waste outputs of heat and pollution. This paper examines how eco-city theory is applied in urban planning and design. The eco-city concept was introduced, international case studies on the eco-cities in developed countries were explored using case study methods to determine the application of eco-city concepts and theories, and a set of recommendations for converting Cairo, Egypt into an eco-city were formulated. Results showed that the eco-city concept can be effectively applied in combination with the characteristics specific to a locality. The study concludes that eco-city theory can be effectively applied in urban planning and design.
\end{abstract}

Key words: Eco-city, Green transportation, Renewable energy, Community participation, Cairo.

\section{Introduction}

Rapid urbanization is arguably the most complex and important socio-economic phenomenon of the 21st century. It represents major and irreversible changes in production and consumption and in the manner by which people interact with nature. Only recently have cities and the urbanization process been viewed through the lens of sustainability, with the reduction of the ecological footprint of a city regarded as a positive contribution to sustainability. This research focuses on the eco-city concept and aims to facilitate the conversion of Cairo into an eco-city in terms of urban planning and design.

\section{Research problem}

The world is becoming increasingly urbanized, with more than half of the global population living in urban areas. The number of urban residents is expected to continue to grow, especially in developing countries. Such expansion will require a wide range of infrastructures, services, housing and employment schemes, and land for development. Urban land expansion can threaten land supply, increase traffic volume and pressure on the environment, and result in massively unsustainable efforts for any city. These issues give rise to the urgent need to act on a number of indicators that have reached critical levels, notably greenhouse gas emissions, water pollution, and biodiversity. So that, cities are in need to apply the concept of eco-cities. Therefore, the paper aims to answer the following questions: 
- What is the concept of an eco-city?

- How can cities initiate and accelerate their ecological transition under difficulties that confront the current context?

- How can cities contribute to the deployment of global and local solutions to these challenges?

\section{Research objectives}

The main aim of this research is to pose recommendations regarding the conversion of Cairo city in Egypt from an unsustainable city into an eco-city, especially in terms of urban planning and design. To this end, the following objectives are considered:

- to build a viable future for humanity within a healthy environment;

- to promote sustainable living and zero carbon development;

- to involve conceptual thinking in environmental urban sustainability;

- to establish a livable and sustainable urban environment;

- to develop the visual image of Cairo by highlighting the importance of the eco-city concept.

\section{Research methodology}

The study explores the eco-city concept from theoretical, analytical, and practical viewpoints for the purpose of sustainability. It seeks to identify the basic features of eco-cities. It also analyzes how the concepts presented in international case studies were developed and explores a practical approach to building sustainable cities. Finally, it uses the eco-city concept as basis in formulating a set of recommendations for developing the urban environment in Cairo.

\section{The eco-city as an approach to sustainable urban development}

\subsection{Definition of eco-city}

"An eco-city is an ecologically healthy city. It is a city built off the principles of living within the means of the environment. The ultimate goal of many eco-cities is to eliminate all carbon waste, to produce energy entirely through renewable sources, and to incorporate the environment into the city; however, eco-cities also have the intentions of stimulating economic growth, reducing poverty, organizing cities to have higher population densities, and therefore higher efficiency, and improving health" [1]. This "also means the city design is strongly informed by knowledge of ecology and its design principles" [2]. "Then we can say that an eco-city is an ideal habitat with a benign ecological circulation in which technology and nature fully merge; human creativity and productivity reach a maximum level; the residents' health and environmental quality are well protected; and energy and materials are efficiently used" [3].

Finally, an eco-city is a city designed with consideration for environmental impacts and is inhabited by people dedicated to minimizing required inputs of energy, water, and food and waste outputs of heat, air pollution, and water pollution. "The eco-city is also known as ecocommunity, sustainable human community" [4]. 


\subsection{Objectives of an eco-city}

Urban planning and design for eco-cities are driven by a number of objectives; to "promote urban transportation system reform that encourages the integration of efficient public transit systems and non-motorized modes (pedestrian and bike paths) and build strong capacity for sustainable urban planning and development through training programs" [5] and community participation.

Beside that, eco-cities aim to "support implementation of green buildings, green transportation, and zero waste plans. As well, help us clean our air, reduce our carbon footprint, lead toward a stable climate future and reduce emissions of greenhouse gases to achieve environmental sustainability. Moreover, eco-cities promote energy efficient through the use of renewable energy sources in urban design operations, enhance waste management to reduce consumption of natural resources, reduce the light pollution through the applications of solar lighting in urban design, maintain water quality standards and an above-average ratio of green space per capita and develop an urban ecosystem which is ecologically sound minimizing the negative impact of development on the environment" [6].

\section{Analysis (case studies on eco-cities)}

This section discusses some international case studies in which the eco-city concept was applied. The following cities are the most eco-cities in the world; (Vancouver-Masdar-Toronto-CuritibaFreiburg-Stockholm-Frankfurt-Portland). The aim of this section is to determine the ecological considerations of each case.

\subsection{Vancouver [7]}

Vancouver is proof that a city can grow and still become an eco-city, as evidenced by its implementation of the greenest building code in North America. Vancouver addresses the challenge of green transportation by infusing investments into endeavors that encourage walking, cycling, and the construction of transit infrastructures instead of new roads. Neighborhoods are developed under renewable energy projects. Vancouver's Eco-city 2020 Action Plan is a strategy for staying on the leading edge of city sustainability, and its target is to reduce Vancouver's ecological footprint. The ecological considerations for urban planning and design in Vancouver are as follows:

-Community participation: The city implemented the community participation concept. Many people contributed their time and ideas to the development of the Eco-city 2020 Action Plan. More than 35,000 people from around the world participated in the process online, specifically through social media, and in face-to-face workshops. More than 9,500 people, most of whom are residents of Vancouver, actively provided recommendations and feedback to help the city determine the best path for achieving the targets delineated in the action plan.

- Green buildings: Policy in Vancouver requires that all buildings constructed from 2020 onward be carbon neutral in operations. The city is leading the way in terms of green building design. Its next challenge is to improve the environmental performance of existing building stock by 
focusing on insulation, heating, and lighting system upgrades and on the use of energy-efficient appliances. All new building re-zoning schemes in Vancouver should comply with the construction industry's LEED.

- Green transportation: Green transportation includes transit, cycling, and walking. Support transportation and active transportation planning that are grounded on land use policies enable a city to satisfy mobility while improving pedestrian safety. Support technologies and infrastructure also reduce the environmental impact of vehicles. Vancouver needs to achieve green transportation targets in order to satisfy its 2020 goals for climate leadership, light footprint, and improved air quality. See figure 1.

- Green spaces: By 2020, all Vancouver residents should live within a five-minute walk to a park, greenway, or other green space. Green spaces benefit residents' physical and emotional health by reducing blood pressure and stress. These spaces also contribute to a sense of community by creating places for recreational activities, for children to play, and for neighbors to meet. The highest priority actions are as follows: (a) Four to six new mini-parks should be constructed by converting street rights-of-way into parks. These parks will be developed in consultation with the local community to determine their use as community gardens, plazas, or community yards. (b) New parks should be constructed in priority neighborhoods and (c) 15,000 new trees should be planted on city land.

Fig (1) The green transportation concept in Vancouver [7].
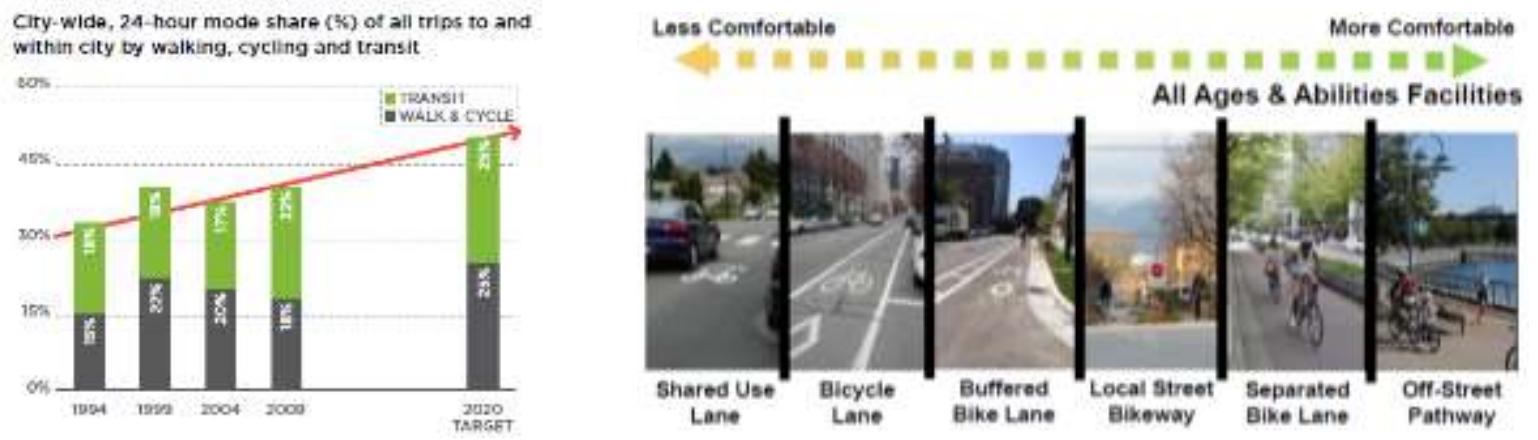

\subsection{Masdar, Abu Dhabi [8]}

Masdar city relies entirely on solar energy and other renewable energy sources to ensure a sustainable, zero-carbon, and zero-waste ecology. To achieve the city's goal of being one of the most sustainable cities in the world, every aspect of the city's urban planning, design, and architecture has been approached with sustainability in mind. In what follows, the applications of integrated photovoltaic technology in urban design are discussed.

-Masdar Plaza: The neighborhood of Masdar Plaza is characterized by distinct buildings. The plaza also has 54 automatically opening and closing sunshades with photovoltaic cells. 
-Masdar streets: Streets are laid out at angles that optimize shading. The long and narrow angles cool prevailing winds and facilitate ventilation in the city (Fig. 2A).

-Masdar, pedestrian friendly: Street infrastructure for pedestrians enables the construction of buildings that are closer together, thereby providing considerable shading and cool streets.

-Masdar, landscaping: The planting areas in the Central Courtyard of the Masdar Institute are irrigated with recycled water (Fig. 2B), most water-based features are shaded to reduce water loss through evaporation, the air temperature in public spaces is reduced through the shading provided by buildings and through planting, to reduce water demand for irrigation, the plants and trees grown in Masdar are indigenous species and some waste wood is reused, whereas others are converted into mulch for use in landscaping around Masdar offices.

-Masdar, sustainable materials: The sustainable materials used for Masdar Institute buildings should be locally sourced. In selecting these materials, the city considers sustainability factors, such as recyclability, low embodied energy properties, and low-emission properties.

-Masdar, landmarks: The wind tower circulates wind to ventilate a public square at its base. The air is cooled by water sprays, wind cones provide natural ventilation and photovoltaic panels power buildings and provide shade that cool roofs (Fig. 2C).

-Masdar, transport: An electric light rail system for the city will reduce energy output and emit no carbon gases. Masdar will be using an automated system of electric vehicles and a public transport system that comprises electric buses, electric cars, and other clean-energy vehicles.

-Masdar, energy management: Masdar city is powered by renewable energy; The Solar Photovoltaic Farm provides clean energy to the Masdar Institute Campus. The photovoltaic array atop campus buildings helps provide $30 \%$ of the base electrical load of the campus. Raised above the laboratories and residential apartments, it also helps provide additional shading to the streets while reducing the amount of direct solar gain absorbed by the heavily insulated roofs.

-Masdar, urban character: The structure of the residential façades was influenced by the use of sand as aggregate for glass reinforced concrete, which provides the cladding its distinctive color (Fig. 3). The marriage of traditional Arabic building practice and modern technologies satisfies demands for style, adaptability, and flexibility while maintaining a sustainable footprint. 
Fig (2) Masdar city, Sustainable Development:

a) Streets in Masdar City [8]

b) Landscape in Masdar City [8]

c) Wind Tower in Masdar City [8]

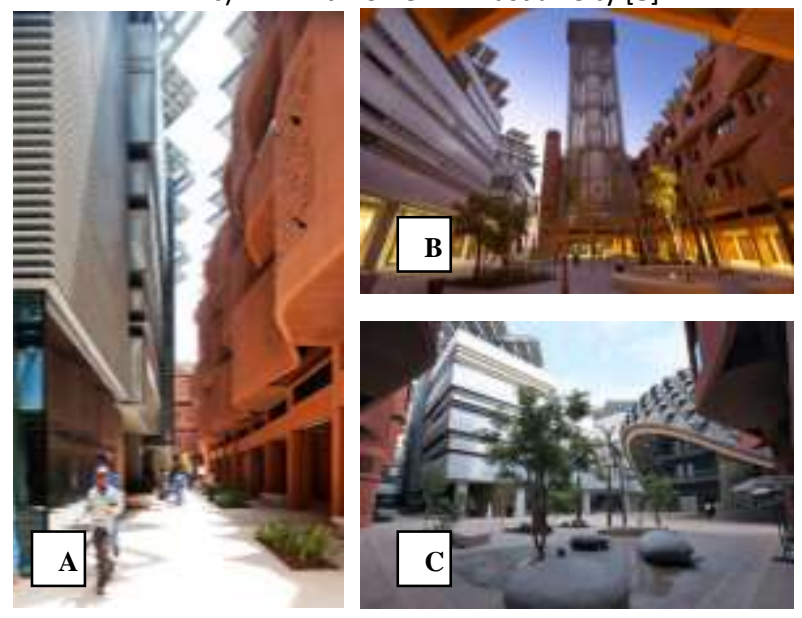

Fig (3) Masdar city,

The form of the residential elevations [8]

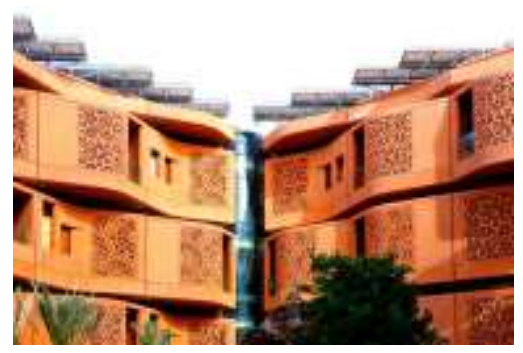

\subsection{Toronto [9]}

Toronto is the highest rated eco-city in North America. Similar to the previously discussed cities, it seeks to transition into a low-carbon economy. To this end, it adhered to some criteria for ecocities; it reduced energy consumption and reliance on carbon-based fuels, it manages stormwater from rain and snow fall and it supports green building design and construction. Besides that, its pedestrian infrastructure is intended to achieve sustainability at the streetscape level through the use of high-albedo surface materials for at least $50 \%$ of a site's nonroof hardscape and reducing the effects of urban heat islands. Moreover, it adheres to design guidelines for greening surface parking lots, it enhances ecology and the natural environment, it plants a minimum of one tree onsite for every $30 \mathrm{~m}^{2}$ of a post-development area covered by soft landscaping and it constructs green roofs (eco-roofs).

\subsection{Curitiba, Brazil [1]}

The city of Curitiba, Brazil proactively addressed the challenges that confront the establishment of an eco-city with a master plan that outlines future integration among urban development, transportation, and public health. This plan was realized in modern Curitiba, which is defined by linear stretches of urban development surrounded by green spaces and low-density residential areas. The city was designed for the mobility of people, not the mobility of cars.

Curitiba maintains the lowest air pollution rates in Brazil and more than 300,000 trees in the city reduce natural flooding. Curitiba has maintained a consistent vision of the future and has worked to attain this goal through careful urban planning that considers transportation while encouraging environmental and public health initiatives. In 2010, Curitiba was conferred the Globe Eco-City Award for its achievements and its understanding of sustainable city development - both regarding policy and implementation. 


\subsection{Freiburg, Germany [10]}

Freiburg, Germany constructed itself as an eco-city by actively committing to its targets for energy, transportation, and its three pillars for sustainable development: energy saving, new technology, and renewable energy sources. One of the largest drivers of the city's success is citizen engagement; local power opposition led to the creation of a campaign for sustainable solutions to the energy needs of the city. A network of environmentalists and research organizations was established to advance the agenda for a sustainable city. In terms of ecology and economy, Freiburg has been extremely successful in conducting research on and marketing renewable energy. In addition to solar initiatives, improvements to the transportation systems of Freiburg have been made over the last four decades. The city is known for its huge pedestrian zone in the city center, where no cars are allowed. By 2030, the city resolves to cut carbon dioxide emissions by $40 \%$, and by 2050 , it aims to be a climate neutral environment. For these reasons, Freiburg is known as a green city. For more than 20 years, it has maintained public parks, guided by principles that encourage working harmoniously with nature. The city is also evaluated as a sustainable model district. All the houses are built for low energy consumption, and the entire district is designed to be car free (Fig. 4).

Environmentally compatible modes of transport, as indicated in the traffic prevention strategy, are underpinned by the encouragement of transport modes that harmonize with urban life and the wider environment. These modes include walking, cycling, and the use of local public transport.

Fig (4) Freiburg,

Solar power plant on the roof of the Badenova Stadium and Solar Settlement [9]
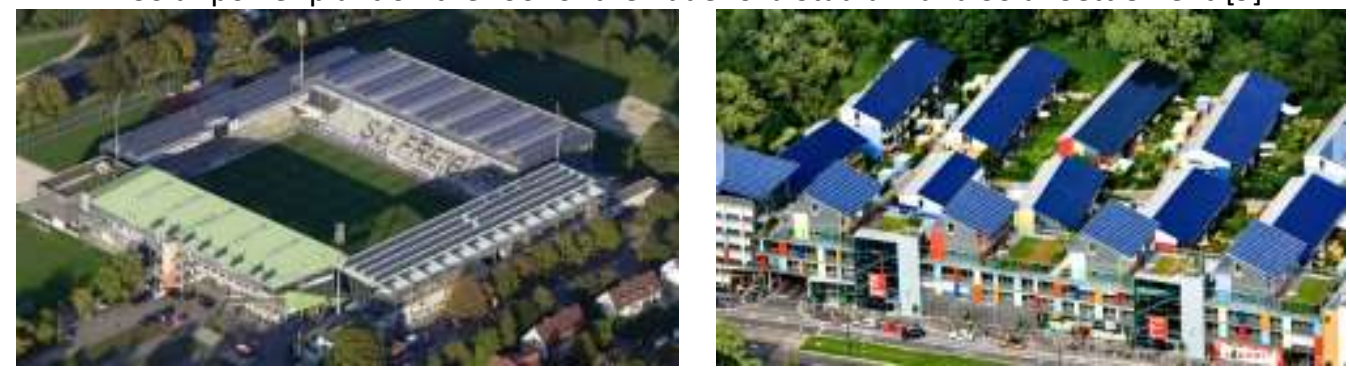

\subsection{Stockholm, Sweden [1]}

Stockholm in Sweden has been an environmentally focused city that is re-developing itself into an eco-city through efficient urban planning and resource use. Stockholm has established six environmental goals that fall under the umbrella called Vision 2030; these goals include the development of efficient transportation, the use of sustainable energy, the promotion of efficient land and water use, the implementation of waste treatment improvements, and the use of safe building and product materials. Beyond Vision 2030, Stockholm intends to be fossil fuel free by 2050.

In terms of urban planning, Stockholm currently requires the re-use of land before urban sprawl can continue. The Hammarby district of Stockholm has become twice as energy efficient as the rest of the city after an environmentally focused re-development. "Stockholm has pursued green 
development and optimization of urban systems. These efforts deemed Stockholm the European Green Capital for "leading the way towards environmentally friendly urban living'" [11]. "Stockholm is known for its extensive parks and green space, Sweden's third-largest city is a model of sustainable urban development. With the goal of making the city an eco-city, several neighborhoods have already been transformed using innovative design and are planning to become more socially, environmentally, and economically responsive. The flat roofs on buildings are being converted into gently sloping roofs with integrated solar cells, to produced energy" [1].

\subsection{Frankfurt}

Frankfurt is home to the world's highest skyscraper. "The Commerzbank Tower in Frankfurt is a symbolic and functional, green building. Though it has climate control, it uses a natural ventilation system for reducing energy consumption, something which makes it the world's first ecological skyscraper". "Its special construction feature, the facade has two shells for the air to freely circulate between them. Another special feature was added, the building is supplied entirely with green electricity, skyscraper's gardens provide additional ecological touches, three each of them are situated in the east, south, and west of the building and offer ideal climatic conditions to the various plants" [12].

\subsection{Portland, Oregon, USA}

Portland is the first US city to enact a comprehensive plan for reducing $\mathrm{CO} 2$ emissions and has aggressively advanced green building initiatives. It also runs a comprehensive system of light rails, buses, and bike lanes to help keep cars off the roads and boasts of 92,000 acres of green space. "The goal is to move toward zero. Traffic-related fatalities "make walking and cycling safe, convenient, comfortable, and fun, and pedestrian improvements through development (street trees-wider sidewalks-bike signals- pedestrian friendly buildings)" [13].

"One of Portland's flagship projects for green building is the Oregon Sustainability Center (OSC) in 2013; the center was "the greenest high-rise ever built," going beyond the design qualifications for LEED certification. The OSC was planned to fulfill the requirements of the Living Building Challenge: As a "net-zero" building, it was carbon-neutral, produce as much energy as it used and recycle wastewater onsite. The project is cooperating extensively with the Oregon University System - the seven state universities - and will act as a laboratory for testing green design ideas. Portland also remains on the sharp end of eco-friendly transportation models. The city has over 315 miles of developed bikeways; as of 2010, Portland had the highest percentage of bike commuters in the country" [14].

\section{Criteria for building eco-cities}

On the basis of the examined international case studies, the most important criteria for moving toward becoming an eco-city were identified. These criteria are listed in the following. 


\subsection{Economic criteria}

The economic criteria can be satisfied through "resource conservation by maximizing efficiency of water and energy resources, constructing a waste management system that can recycle waste and reuse it and creating a zero-waste system, decreasing material consumption and increasing awareness of environmental and sustainability issues. Over that, the movement away from carbon-producing energy sources to more renewable energy sources, such as wind, water and solar power, and public transportation system that makes the priority methods of transportation as follows possible: walking first, then cycling, and then public transportation" [12].

"Eco-cities look to design buildings with natural ventilation systems; eco-cities reduce the need for air conditioning, thus, drastically decreasing commercial and residential energy use" [1].

\subsection{Environmental criteria}

"Eco-cities employ vertical landscaping, as methods of decreasing the environmental impact of land use. Additionally, vertical landscaping lower urban temperatures and help prevent the heat island effect allows for rainfall collection" [1] and "conserve energy through energy-efficient landscaping" [15]. This approach includes the following measures: "planting trees for the purpose of providing shade, which reduces cooling costs; green roofs that cool buildings with extra thermal mass and evapotranspiration; reducing the heat island effect with high albedo paving, shade, and minimizing paved areas; site lighting with full cut off fixtures and high efficiency fixtures" [15]. Furthermore, eco-cities look to employ renewable energy sources, such as wind turbines and solar panels, to reduce emissions.

\subsection{Social criteria}

An eco-city should be designed with lively spaces where people can see and be seen by other people. The image of the city and its attractiveness to visitors depend, to a large extent, on its street and open space life. A social eco-system must achieve distributional equity and adequately provide social services. "Urban developments in order to be socially sustainable should create a harmonious living environment, reduces social inequality, townscape design, preservation of local characteristics and improves quality of life in general" [16].

\subsection{Urban criteria}

At the urban level, eco-city criteria aim at restoring ecological continuity through the application of the factors discussed in the previous sections, aside from focusing on the ecological trends in building and urban environment design. These trends include the promotion of energy efficiency in buildings, building re-use, reduced water use, and access to public spaces and community walkability, in addition to the "preservation of local characteristics and heritage items" [17].

Moreover, an "eco-city can achieve sustainable transportation through the use of renewable resources, minimizing consumption of non-renewable resources, reusing and recycling its 
components, reducing carbon emissions on all transport modes" [18], and optimizing the use of electric vehicles, completed streets, and sustainable transportation infrastructure.

An eco-city can achieve water efficiency through the application of water-sensitive urban design, which pertains to "a land planning and engineering design approach which integrates the urban water cycle, including stormwater, groundwater and wastewater management and water supply, into urban design to minimize environmental degradation and improve aesthetic" [15].

\section{Case (practical) study on Cairo, Egypt}

First, this section documents the most important problems that confront the urban environment in Cairo. These problems impede the transition of the city into an eco-city. Second, it presents the set of future recommendations that were formulated on the basis of the sustainability framework for establishing a more ecological urban environment in Cairo.

Objective: This section discusses the promotion of sustainability and attractive solutions that contribute to the transition of Cairo into an eco-city.

\subsection{Documentation of the problems confronting Cairo's urban environment}

Cairo is experiencing problems that prevent its transition into an eco-city.

\subsubsection{Urban problems}

Cairo is a historical city; it is an ancient urban region and a center for culture and civilization. The city currently suffers from numerous urban and environmental problems, such as deteriorating urban design and physical character, high population density due to rapid urbanization, environmental pollution from old vehicles, traffic congestion

Caused by poor transport distribution, and an unsustainable urban transportation infrastructure. The Fig (5) Traffic congestion in Cairo unsustainable streetscape operation equally contributes to the degradation of Cairo's urban environment (Figs. 5). This degradation is caused by congestion, especially in the downtown area, and by the unexpected overlap in the envisioned political, commercial, and administrative uses of urban spaces.

\subsubsection{Economic problems}

Cairo suffers from many of the economic problems. These problems are manifested in the some aspects such as; Lighting in most of the streets is energy inefficient, the "sky glow" produced by the over-illumination of urban areas negatively affects energy consumption, unsustainable materials are used for streetscape operations and photovoltaic applications in urban design and wind turbines or solar panels are lacking. 
Besides, Cairo lacks waste management initiatives. "In 2002, international waste management companies started operations in Egypt, particularly Cairo, Alexandria and Giza governorates. However after ten years of participation in solid waste management in Cairo, their performance has been dismal. In 2009 Egyptian government acknowledged that solid waste management has deteriorated alarmingly after the entry of foreign companies".

Over that, slums abound in scattered areas, buildings are in bad condition, and very narrow streets are constructed. Many areas cannot be provided with efficient infrastructure

(Waste management/disposal, water supply, electricity) (Fig. 6).

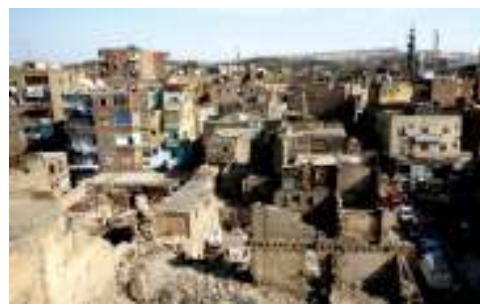

Informal settlements in Cairo
Fig (6) Urban image degradation in Cairo
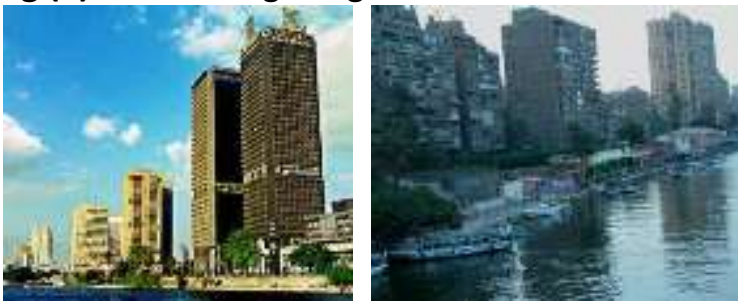

Non-reflective the historical and cultural context (Ref. : Google Earth)

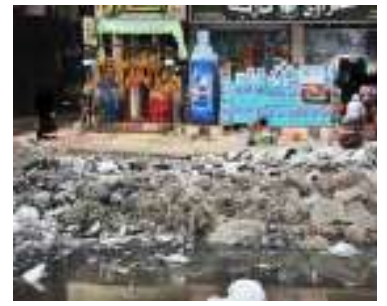

Waste management

\subsubsection{Social problems}

Cairo lacks urban parks that should preferably be situated in the heart of the city to connect all urban spaces. This deficiency impedes accessibility, prevents the construction of lively spaces, and negatively affects the health of the residents. Most urban spaces are constructed without consideration for the principle of liveliness and most pedestrian sidewalks and vehicle lanes are inadequately separated, and no seating elements are provided in transportation stops.

Besides, community participation is not a component of urban design development processes. And the construction of buildings that do not conform to sustainability principles disregards the architectural character of a place, thereby negatively affecting the city's identity and sense of place and culture. The city is characterized by deficient social equity, which is due to the poor distribution of urban open spaces, especially child-oriented spaces.

\subsubsection{Environmental level}

Cairo suffers from many environmental problems, but the primary challenge that confronts the city revolves around ecological problems. Cairo is heavily polluted by emissions from car exhausts, inefficiently managed garbage disposal, and agricultural waste burning. Additional problems include stormwater planters play an important role in sustainable urban design because these minimize stormwater runoff, yet the city does not employ such tools. The River Nile is polluted with large quantities of industrial, agricultural, and domestic wastewater and the heat island effect increases because of the shortage in green roofs in most buildings. This increase, in turn, negatively affects the air quality and image of the city. 


\section{Recommendations for conversion of Cairo city in Egypt into an eco-city}

Reducing the Cairo's ecological footprint is essential to sustainability.

\subsection{Urbanization recommendations}

At the level of urban problems, many methods can be applied. The cultural heritage of the region in terms of historical urban classification (which includes phases of growth, street network hierarchy and design, texture of building lots, land-use patterns) should be respected. A balanced residential, employment, and educational uses should be also organized. Walkable urbanism should be promoted through measures such as the construction of walkable streets and accessible open spaces.

In case of Egypt, for example, pathways should be designed as public spaces with highly sustainable streetscapes. Public events should also be geared toward promoting sustainability (e.g., activities that encourage walking/cycling and social control initiatives). Also, priority should be given to the public transport and mixed-use areas should be promoted. Additionally, land use should be characterized by a balance of residential, business, and production purposes (mixed used urban environment). This concept also refers for establishing a combination of facilities, such as public spaces to which green areas are integrated.

\subsection{Economic recommendations}

The fact that the next generation of economy will be a "green solar economy" that depends on the maximization of renewable energy applications should be taken in account. Thus, the priority should be accorded to sustainable modes of transport (pedestrian lanes, cycling, public transport). The low energy consumption should be promoted through the adoption of renewable energy and water consumption should be minimized through the construction of rain gardens. Environmental-friendly and renewable materials should be maximized and the maintenance needs for such measures and material recycling should be reduced.

In case of Egypt, The use of green roofs, which improve energy efficiency, should be sustained. As it reduce the amount of energy needed to moderate building temperature. Lighting efficiency can be enhanced using passive solar applications and design not only in building design but also in urban design. The recycling of resources within the city systems and the minimization of waste outputs (to protect the environment) should be incorporated through a national program and project depending on the national Egyptian labor capacities. A new set of policies that help sporting new green small industries will be needed.

\subsection{Environmental recommendations}

Air pollution emissions as the main element affected the environment should be minimized through several actions. For example, sustainable transportation, the adoption of green roofs should be promoted as they will improve the aesthetic aspects of air quality, reduce the amount of stormwater runoff, minimize the urban heat island effect, and improve air quality in general. 
The consumption of energy and natural resources should be reduced. Thus, the energy efficiency of buildings and urban components should be optimized.

In case of Egypt, clean air quality should be improved by reducing traffic emissions, which forms a great part of the problem of air pollution and " heat island effect" in Cairo. Such reduction can be achieved by an integrated system of public sustainable transport to reduce adverse environmental health impacts, and establishing open and green spaces, such as public parks or planting greenery in streets and squares. People should be aware of environmental policies of waste management to reduce the consumption of natural resources. In addition, attention should focus on sustainable landscaping throughout the city to reduce wastage of water and electricity.

\subsection{Social recommendations}

Generally, Community engagement should be supported and social live should be redesigned within urban development projects. The amount of parks, open and green spaces and recreational facilities should be increased to facilitate social contact. The accessibility, beauty, safety, and cleanliness of public spaces should be enhanced. Streets and urban spaces should be designed as lively spaces where people can participate social designed activities. In this real, the new policy of aiming at creating new open space and parks through the existing urban context of the greater Cairo such as "Embaba Airport Park" should be sustained.

The vision for eco-cities can become a reality only through implementation. On this basis, a necessary requirement is to apply the following policies, as seen in Table 1.

Table (1)

The objectives of convert Cairo to an eco-city

\begin{tabular}{|l|l|l|l|l|l|l|l|l|l|}
\hline & $\begin{array}{c}\text { Improve } \\
\text { Air } \\
\text { Quality }\end{array}$ & $\begin{array}{c}\text { Improve } \\
\text { Energy } \\
\text { Efficiency }\end{array}$ & $\begin{array}{l}\text { Promote } \\
\text { Lively } \\
\text { Spaces }\end{array}$ & $\begin{array}{c}\text { Reduce } \\
\text { Heat } \\
\text { Island } \\
\text { Effects }\end{array}$ & $\begin{array}{c}\text { Reduce } \\
\text { Light } \\
\text { Pollution }\end{array}$ & $\begin{array}{l}\text { Improve } \\
\text { Water } \\
\text { Quality/ } \\
\text { Efficiency }\end{array}$ & $\begin{array}{l}\text { Strengthen } \\
\text { identity\& } \\
\text { Sense of } \\
\text { Place }\end{array}$ & $\begin{array}{l}\text { Economic } \\
\text { Efficiency }\end{array}$ \\
\hline $\begin{array}{l}\text { renewable energy } \\
\text { applications }\end{array}$ & & & & & & & & \\
\hline $\begin{array}{l}\text { renewable \& reused } \\
\text { materials }\end{array}$ & & & & & & & & \\
\hline Solar lighting & & & & & & & & \\
\hline green spaces \& parks & & & & & & & & \\
\hline green roofs & & & & & & & & \\
\hline & sustainable transport & & & & & & & & \\
\hline
\end{tabular}

Ref.: The author. 


\section{Conclusion}

In recent years, cities all over the world have developed construction systems that incorporate the idea of creating urban environments that are more ecological and livable. The strategies adopted place considerable emphasis on achieving harmony between humans and nature as urban planning and design are carried out. The eco-city concept indicates that planning for sustainability translates to ecology-based community planning with the aim of conserving global resources.

This study developed a framework for moving toward a more ecological Cairo through the analysis of some international case studies that applied the eco-city concept. This paper has presented future recommendations that are specific to the Egyptian context; the recommendations revolve primarily around promoting sustainable transportation, providing attractive and livable public and green spaces, integrating cultural heritages to create varied surroundings, enhancing sustainable structures that contribute to the health, safety, and wellbeing of inhabitants, using renewable energy sources, and promoting community engagement. 


\section{References}

[1] Eco-cities for India, Jun 20 (2011). http://india.Carbon-outlook.com/content/eco-cities-India.

[2] Eco-cities, From Wikipedia, the free encyclopedia (2014). http://en.wikipedia.org/wiki/Eco-cities\#Landscape

[3] Energy-efficient landscaping, From Wikipedia (2014). http://en.wikipedia.org/wiki/Energy-efficient_landscaping

[4] Faller R, et al. (2010) eco-city towards sustainable urban development: Stockholm.

[5] Foster N (2008) Green Industrial Revolution: Free University, Berlin.

[6] Green City Freiburg (2011) http://www.fwtm.freiburg.de/servlet/PB/show/1199617_I2/GreenCity.pdf

[7] Jacques $\mathrm{H}$, et al. (2011) Mobilizing Cairo: http://tiffanywey.tumblr.com/cairo

[8] Mak M, et al. (2011) Social Sustainability: A Comparison of Case Studies in UK, USA and Australia, School of Architecture and Built Environment, The University of Newcastle, Australia, 17th Pacific Rim Real Estate Society Conference, Gold Coast, $\mathrm{p} 4$.

[9] Maruyama H (2010) Eco2 Cities: Ecological Cities as Economic Cities: World Bank Publications. p. 170.

[10] Masdar City (2011), the Global Centre of Future Energy, Abu Dhabi, UAE

[11] Register R (2014) Eco-cities of Tomorrow: New Mexico.

[12] CITIC Building, (2014) Sustainable Cities: China.

[13] Sustainable Transportation (2013) government of Canada: Canada.

http://www.ec.gc.ca/air/default.asp?lang=En\&n=1036DBDC-1, 7/2/2013.

[14] Greenest Cities: Portland, Oregon, 2011, http://ecohearth.com/eco-zine/travel-and-leisure/1634-greenestcities-portland-oregon.html

[15] Suzuki H, et al. (2010) Eco-Cities: Ecological Cities as Economic Cities: World Bank Publications.p. 170.

[16] Transportation 2040, implementation report, walking and cycling safety (2013)

http://former.vancouver.ca/ctyclerk/cclerk/20130612/documents/cfsc2presentation.pdf

[17] Vancouver's Greenest City Action Team (2012) Action Plan 2020- Greenest City: City of Vancouver, Canada.

[18] Welsh J (2010) Making a sustainable city happen Toronto Green Standard: Toronto.

[19] Zafar S (2012) Waste Management in Cairo, Ecomena. http://www.ecomena.org/garbage-cairo/

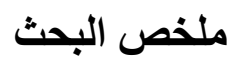

المدينة البيئية/ الايكولوجية هي المدينة التي صممت وبنيت مع الأخذ في الاعتبار الآثار البيئية. فهي تعتمد على التقليل إلى الحد

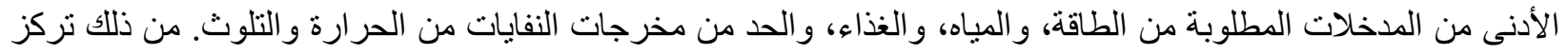

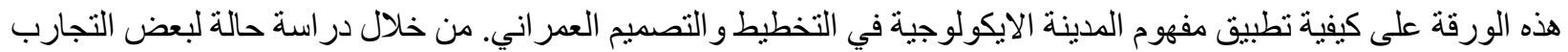

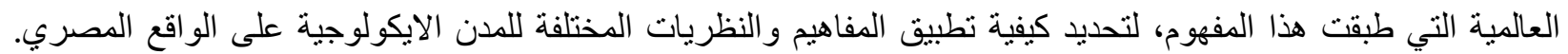

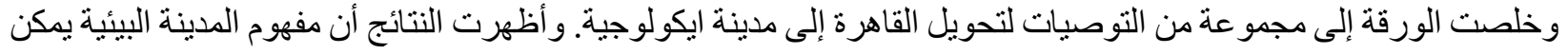
تطبيقها بشكل فعال عند تكامل الخصائص المحددة لهذا الفكر. وتخلص الدر اسة إلى أن نظرية المدينة الايكولوجية يمكن تطبيقها بفعالية في عمليات التخطيط و التصميم العمر اني. 